Article

\title{
The Majella National Park: An Aspiring UNESCO Geopark
}

\author{
Elena Liberatoscioli ${ }^{1, *}$, Giancarlo Boscaino ${ }^{2}$, Silvano Agostini ${ }^{3}$, Adele Garzarella ${ }^{4}$ and \\ Etta Patacca Scandone 5 \\ 1 Ente Parco Nazionale della Majella, 67039 Sulmona, Italy \\ 2 Ordine dei Geologi della Regione Abruzzo, 65100 Pescara, Italy; giancarlo.boscaino@geologiabruzzo.org \\ 3 Soprintendenza Archeologia, Belle Arti e Paesaggio dell'Abruzzo, 66100 Chieti, Italy; \\ silvano.agostini@beniculturali.it \\ 4 Dipartimento di Ingegneria e Geologia, Università “G. D'Annunzio" di Chieti-Pescara, 66100 Chieti, Italy; \\ a.garzarella@unich.it \\ 5 Università di Pisa, 56100 Pisa, Italy; patacca@dst.unipi.it \\ * Correspondence: elena.liberatoscioli@parcomajella.it; Tel.: +39-0864-257-0417
}

Received: 31 May 2018; Accepted: 5 July 2018; Published: 10 July 2018

\begin{abstract}
Majella National Park is located in the central Apennines (Italy), in a vast mountainous area of about $740 \mathrm{~km}^{2}$. Owing to the complex geological history of the Majella Massif and surrounding areas, it features many different landforms. Woodlands rich in water characterize the wide tectonic depression of Caramanico, which separates the rounded gentle profile of the Majella to the east from the impervious steep slope of the Morrone Mt. to the west. Bare pitted highlands, like lunar landforms, characterize the top of the Majella (i.e., Femmina Morta Valley) shaped by flowing ice that long ago covered the higher parts of the massif. Sedimentary structures and fossil content recovered in carbonates attest to a long period of sedimentation in warm, shallow-marine environments, revealing that the Majella and the surrounding carbonate mountains looked, approximately from 140 to $7 \mathrm{Ma}$, like the present-day Bahamas and Persian Gulf. The Park hosts at least 95 geosites, some of which (22) are well-known in the international literature because of their scientific relevance. In addition, its natural and cultural wealth, deeply fused together with geoheritage, preserves several features of national and world rarity. Therefore, the Park Authority decided to put forward its territory as a candidate to become part of the United Nations Educational, Scientific and Cultural Organization (UNESCO) Global Geoparks Network.
\end{abstract}

Keywords: aspiring geopark; geosite; Majella; central Apennines; Meso-Cenozoic; carbonate platform

\section{Introduction}

The aim of this paper is to present the geological peculiarities of the Majella National Park (MNP) together with other natural and cultural main wealths, as well as the history of the park and its network of facilities for tourists, features that motivated the Park Authority to propose it as a candidate to become a United Nations Educational, Scientific and Cultural Organization (UNESCO) Global Geopark.

Geoconservation concerns the protection of peculiar places on Earth, that represent open windows on the past [1]. It was first introduced among the other conservation disciplines by the European Working Group of Earth Science Conservation in 1988, that turned into ProGeo, the European Association for the Conservation of Geological Heritage, in 1993.

The main focus of the Geosites Project, promoted by the International Union of Geological Sciences (IUGS) in 1994, was to involve the global geological community in providing inventory and data 
to support national and global outreach to protect geological resources for scientific and education objectives. Its goals were designed to mesh with national and global initiatives and address the issue of how best to represent the diversity and richness of key geoscientific sites [2]. In 1995, ProGeo promoted a project aimed to compile a list of European geosites. At the end of the same year, IUGS, with the support of UNESCO, promoted the project of implementing a global inventory and related database.

Geoparks comprise substantial territorial areas within which there may be several geosites [3]. They are also concerned with promoting sustainable development and tourism [4]. UNESCO's work with geoparks began in 2001. In 2004, 17 European and 8 Chinese geoparks met at UNESCO headquarters in Paris in order to establish the Global Geoparks Network (GGN) [5]. During the 38th General Conference of the Organisation, in November 2015, the 195 Member States of UNESCO ratified the creation of the UNESCO Global Geoparks label, that expresses governmental recognition of the importance of outstanding geological sites' and landscape management.

The system of protected areas and nature conservation legislation vary greatly around the world, but there are important geoconservation efforts being made in the UK, Australia, New Zealand, United States, Canada, Europe, and some countries elsewhere in the world. The Geoparks network, since the beginning, has been stimulating thinking about geological conservation in many developing countries where few efforts have been made in the past. UNESCO has played an important role in supporting the Global Geoparks initiative mainly because of the interdisciplinary and international nature of the co-operation in studying Earth systems while also sustaining local communities [3].

In Italy, there has been an upsurge of interest in geoconservation, partly through the passing of the outline law on protected areas (Law no. 394/91). The law aims to protect geological and geomorphological features of national or international significance due to their "natural, scientific, aesthetic, cultural and recreational value" [6].

\section{Location}

MNP, the aspiring Geopark, is located in Abruzzo, a region of central Italy, about $150 \mathrm{~km}$ from Rome (Figure 1). It includes 39 municipalities (4 of them having their historical center inside the protected area) distributed in 3 provinces (Chieti, L'Aquila and Pescara). It is located in the heart of the Apennines very close to other national parks (namely Abruzzo-Lazio-Molise National Park to the south and Gran Sasso-Laga National Park to the north). 


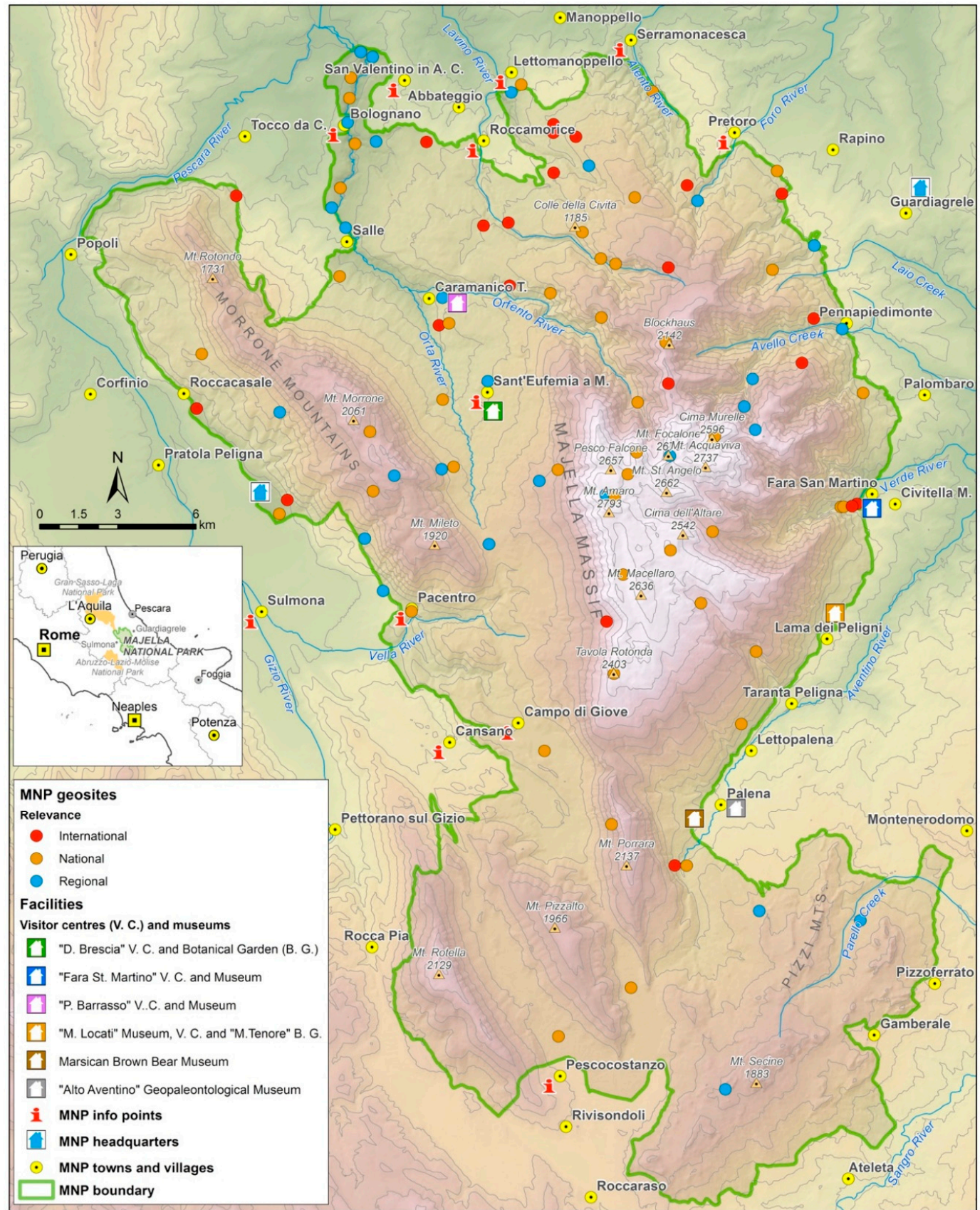

Figure 1. The map shows the territory of the Majella National Park (MNP) with its towns and villages, main peaks and rivers, the network of facilities (info points, visitor centers, museums, botanical gardens, and park's headquarters), other than international, national and regional geosites' location. Base cartographic data: MNP and Region Abruzzo. Map elaboration: E. Liberatoscioli (2018).

\section{Material and Method}

The huge amount of publications available on geoconservation, geoheritage, geoparks and geosites subjects were very important while writing the Majella aspiring Geopark dossier needed to gain admittance to the UNESCO GGN. The published works of Wimbledon, Gray, Henriques, Ruban, Bradbury, Habibi and other authors [1,3,4,7-13] allowed work to start on the aforementioned dossier from an important and interesting framework of information and rules for selecting the geosites of the Majella National Park. 
An important starting point was the first group of 17 geosites listed in 1999 by the Majella National Park's management plan, and the 31 listed in 2014 on the occasion of the Natura 2000 Sites' Plan editing. In 2005, the Geological Survey of Italy (currently belonging to Ispra-Istituto superiore per la ricerca e la protezione ambeintale) founded a National Project on Geological Heritage and Geodiversity [14,15] and started compiling the National Geosite Inventory. Almost 191 geosites have been mapped in the Abruzzo region.

In this paper, and while compiling Majella aspiring Geopark's Geosite Database (GD), a simplified version of the Ispra geosite inventory format [14] was used. It represents the Italian standard for those are wishing to make a geosites' inventory and are planning to propose its incorporation in the national inventory [15]. This is another goal of MNP. In fact, the work for preparing the UNESCO dossier has not had the intention to achieve a complete inventory of MNP geosites, although it may be considered a first attempt towards it, but to give an idea of the geoabundance and geodiversity of the area as conceptualized by [8]. The simplified format contains geographical and geological information about each site, with an emphasis on their usability and accessibility. It also integrates the UNESCO rules in order to evaluate the relevance of the geological heritage of the aspiring geoparks, based on the international peer-reviewed, published research conducted on the geological sites within the area, or citing them.

Therefore, the GD comprises the following fields: an alphanumeric ID, the name of the geosites, the relevance (RELEVANCE: $\mathrm{I}=$ International; $\mathrm{N}=$ National; $\mathrm{R}=$ Regional), the value (VALUE: $S=$ Scientific; $E=$ Education; $G=$ Geotourism), the main interest (TYPE), the location (name of the municipality). Last, but not least, the accessibility is evaluated, considering roads and trails of the MNP included in their classification (condition, difficulty, etc.), but also protection measures which straighten or interdict the access to a few geosites. Moreover, a list of the main references per each identified geosite was prepared. The main interest (TYPE) is coded with an abbreviation consisting of two capital letters: Stratigraphy and sedimentology (ST); Structural geology (SG); Palaeontology (PA); Geomorphology (GM); Hydrology and hydrogeology (HD); Quaternary geology and archaeology (QA); Mining and industrial archaeology (MA); Hydrocarbon genesis and migration (HM). As about half are geomorphosites, a second distinction has been operated (even if not reported in this paper) on the basis of the type of geomorphic processes and landforms: Karst (GM1); Glacial (GM2); Glacio-karst (GM3); Fluvial and fluvio-lacustrine (GM4); Morphotectonic (GM5); Mass-movement (GM6); Erosion (GM7); Various and viewpoints (GM8). These types were chosen starting from the Ispra classes, named "Scientific interest", present in the section C of the aforementioned geosite inventory format.

We compared the MNP types with the 21 types of geosites distinguished by [8,9]. Some differences are due to the intention to fit better to the MNP's geological features and to the goals of the dossier for applying to the UNESCO GGN. Another difference with the Ispra geosite inventory format is the following: the format reports "Geotourism" as a class of "Scientific interest" while in this paper and in the aforementioned dossier it is part of the VALUE which is an attribute of each recorded geosite. Moving back to the GD, many of the occurrences could be attributed to a second type (the Ispra secondary "Scientific interest") as important as the first one. In this paper, we considered only the primary type (i.e., the Ispra "Scientific interest") defined on its representativeness in relation to the territory of the aspiring Geopark. Moreover, sites with a particular panoramic position or that are good for the observation of geological landscape are identified and encoded too. In the GD, the alphanumeric ID code, assigned to each geosite, is made of three letters referring to the municipality followed by a progressive number consisting of three digits (i.e., sul001). The name assigned to each geosite is composed by the primary, and sometimes the second geological interest or phenomenon, and the locality, namely the most important and closest toponym from the 1:25,000 topographic map by the IGM (Istituto Geografico Militare), the main Italian official cartographic body. A new map showing the GD occurrences has been elaborated by means of ArcGIS 10.3, ESRI, Redlands, CA 92373, USA (Figure 1). 


\section{General Features of the Majella Aspiring Geopark}

\subsection{Geographic and Climate Outline}

The aspiring Geopark covers more than $740 \mathrm{~km}^{2}$ (74,095 hectares). It is made up predominantly of carbonate reliefs separated by valleys and karst plateaus and it presents a great morphological and altitudinal variety (130-2793 m). The wide area of Majella Massif has more than 60 peaks, half of them exceeding $2000 \mathrm{~m}$ a.s.l., like Mt. Amaro $(2793 \mathrm{~m})$ the second highest peak of Apennines, followed by: Mt. Acquaviva (2737 m), Mt. Focalone (2676 m), Mt. St. Angelo (2662 m), Mt. Macellaro (2636 m), Cima Murelle (2598 m), Pesco Falcone (2546 m), Cima dell'Altare (2542 m) and Tavola Rotonda (2403 m). Other than Majella, there are the narrow and elongated reliefs of Morrone Mts. (whose homonym main peak is $2061 \mathrm{~m}$ elevated), the mountains of Porrara (2137 m), Rotella (2129 m) and Pizzalto (1966 m). Toward the south-west, the Pizzi-Secine Mts. rises up, less high than the previous ones but still exceeds $1880 \mathrm{~m}$ a.s.l. The high altitudes together with proximity to the sea (Adriatic Sea at just $30 \mathrm{~km}$ ) guarantee a rigid but also variable climate that makes this a unique park, preserving the most rare and valuable part of Italian biodiversity. The main watercourses are: the Orta and the Orfento rivers, the upper part of the Lavino River (Santo Spirito-Capo Lavino Creek), the Gizio and the Vella rivers, which belong to the Pescara River basin, the Aventino and the Verde rivers, the Avella, the Laio and the Parello creeks which belong to the Sangro River basin, and the Foro and the Alento rivers. The eastern Majella is carved by a series of canyons, namely the Mandrelle-Santo Spirito, the Taranta, the Izzo and the Lettopalena valleys, which despite their barren appearance contribute to increasing the water amount of the Sangro basin. Noteworthy are the so called "quarti", karstic highlands which belong to the "Altipiani Maggiori d'Abruzzo" (main Abruzzi highlands). These plateaus extend in the south-western part of the aspiring Geopark, at an elevation of about $1250 \mathrm{~m}$, and are: Quarto Santa Chiara, Quarto Grande, Quarto del Molino and Quarto del Barone. Small and few, but even more important for wildlife, are the perennial water bodies: the Ticino Lake, near Campo di Giove, and the Battista and Pietra Cernaia lakes, south-eastward. With a slightly elliptical shape and the major axis oriented N-S, the aspiring Geopark is characterized by a typical mountain and high-mountain climate with particularly abundant snowfalls. Cool and breezy during summer, the climate presents cold and rainy winters in the lower areas, often maintaining quite good weather conditions and visibility at high altitudes. Spring does not last long, quickly giving way to summery conditions, whereas during the autumn weather is more stable since it is mitigated by the presence of the nearby Adriatic Sea.

\subsection{Natural and Cultural Wealth}

The Majella aspiring Geopark is extremely rich in sites of naturalistic, historical, artistic and cultural interest. Some examples are: in the northern part of the Park, the Orta Valley, one of the most fascinating canyons in this protected area; almost at the opposite extreme, in the south sector at the foot of Mt. Pizzalto near the village of Pescocostanzo, the St. Antonio's Wood is a beautiful case of ancient wood mainly composed by beech, with hundreds of centennial monumental specimens. Beech woods are in fact the most common wood formation within the park. Worth mentioning are those of Lama Bianca as well as those in the Foro Valley, at Palena and in Pizzoferrato. Very interesting and spectacular, although not numerous, are also the park's perennial streams, like the Orfento River (MNP North West) and St. Giovanni's waterfall, in the territory of Guardiagrele, one of the main towns of the area (Figure 1). The latter is one of the few sites where the Fiori Butterwort, a little and rare worm-eating plant, grows.

Among the numerous visitable caves, the Cavallone Cave in the Taranta Valley is to be mentioned. It is known for having inspired the setting of Gabriele D'Annunzio's tragedy "La figlia di Iorio". Its entrance is located at $1475 \mathrm{~m}$ a.s.l., and therefore it is the highest touristic cave in Europe, reachable by means of a panoramic cableway.

Worth a visit are also the numerous hermitages (about 40) built or carved especially on the Majella and on the Morrone rocky slopes by shepherds and hermits and mostly placed in very spectacular 
but not so accessible naturalistic contexts in the northern sector of the park. Two examples are St. Bartolomeo di Legio's (Figure 2) and St. Giovanni's hermitages, both located in the northern and north-western area of the park and the latter is only reachable by crawling in the final part of the way along a stone ledge. Other religious places to be seen are the Madonna dell'Altare Hermitage, visited by Pietro da Morrone who later became Pope Celestino V, and the beautiful and famous Benedictine Abbey of St. Liberatore a Majella. Near the Abbey, along an easy itinerary leading to the source of the Alento River, it is possible to admire the stone tombs of the early Christian era. This site is also interesting from a botanical point of view, thanks to the presence of the rare Bladdernut (Staphylea pinnata). In addition to the aforementioned historical sites, the park hosts, moreover, some notable examples from the Italic and Roman era: Juvanum, at Montenerodomo, an important roman city of the first century BC, and the Italic Sanctuary of Ercole Curino Temple, at the foot of the Morrone mountain ridge just outside Sulmona, the largest MNP town (Figure 1). The dry-stone buildings are typical testimonies of ancient agricultural and pastoral activities, and they are widespread within the entire territory of the park, but above all along the northern side. Some of these, like the ones located in the Giumentina Valley in the territory of Abbateggio, or those in the territory of Roccamorice, two villages of the MNP (Figure 1), are particularly complex and show the locals' great intelligence and building skill. These structures were created only with locally available materials: the stones removed from the cultivated fields were employed using the false vault technique (tholos), which was common in the Mediterranean area during the Prehistoric Era. Today a lot of these structures, inserted in a mainly re-naturalized environment, can be visited thanks to dedicated itineraries. In the territory of the park, some important castles are also present, including the fourth-century castle at Pacentro, a peculiar village sited along the western side of the Morrone mountains, and the remains of the striking Menardo Castle at Serramonacesca, another MNP village standing in the northern part of its territory (Figure 1). Especially interesting is, finally, the Bandit's Board, which shows the names and thoughts of some of the bandits that were active in this territory after the Italian state's unification.

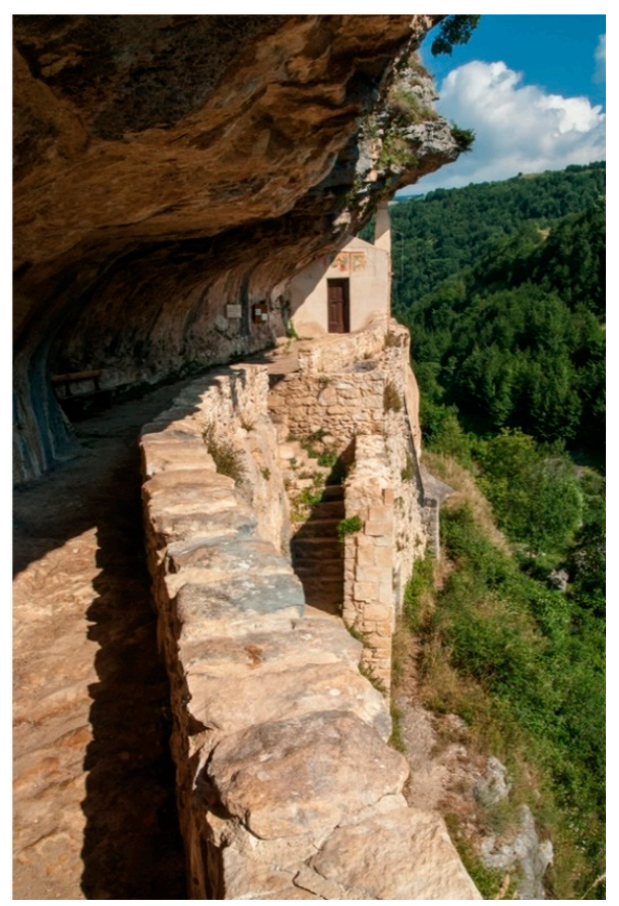

Figure 2. The St. Bartolomeo in Legio's Hermitage on the northern side of the Majella Massif. Most hermitages are located in the numerous canyons and caves of the park, as well as on steep slopes, and are as a result deeply fused with the rock. Photo: MNP Archive/M. Anselmi. 
Other attractions are: the aforementioned Sulmona, birthplace of poet Ovidio and city with many monuments, located near to Morronese Abbey (which hosts the technical headquarters of MNP), St. Onofrio's Hermitage and the remains of the Italic Sanctuary of Ercole Curino, other than some towns which are often well conserved, namely Pescocostanzo, one of the most striking historical centres of the park, Fara San Martino, Palena, Rapino, known for its pottery, and Guardiagrele, an old town where the legal headquarter of the MNP is sited (Figure 1).

\subsection{Short History of the Aspiring Geopark and Regulation}

As specified above, the area of the aspiring Geopark corresponds to the territory of MNP which was instituted in 1991 with the Frame Law on Natural Protected Areas (no. 394 on December 6th, 1991). This institution means that the park holds a nationally and internationally relevant natural and cultural heritage. The national code of the MNP, as reported in the official list of Italian protected areas, is EUAP0013. As proof of the significant natural and cultural value of the area, it should be mentioned that before the 1991 law, seven national reserves (protected areas) had been established in the same area, the oldest of which was founded in 1971 (Valle dell'Orfento Natural Oriented Reserve). Another four regional reserves, established before the institution of MNP by Region Abruzzo, complete the framework of the protected areas recognized in the territory's application to become part of the UNESCO GGN.

All the aforementioned national and regional reserves are currently part of the MNP. On 5 June 1995, by decree of the president of the Italian republic and with the institution of the Park Authority, the ordinary managing activity of the territory was initiated. The Park Authority is a non-economic public entity under the supervision of the Italian Ministry of the Environment and Protection of Land and Sea. The legal and administrative headquarter of the Park Authority is located in Guardiagrele $(\mathrm{CH})$, while its operative and technical headquarter is in Sulmona (AQ). The MNP Plan, approved in 1999 by the Directive Council of the Park Authority, was adopted in 2005 and later underwent the approval of the Regional Council of Abruzzo. After being published in the Official Gazette of the Italian Republic in 2009, it definitively entered into force.

The territory of the MNP, as it is determined in the national Law 394/91, is divided into 4 areas, denominated as " $\mathrm{A}$ ", " $\mathrm{B}$ ", " $\mathrm{C}$ " and " $\mathrm{D}$ " depending on the different level of protection needed. More precisely, in the " $\mathrm{A}$ " area-Integral Reserve-the environment is conserved in its integrity. The " $\mathrm{B}$ " zone-Oriented General Reserve-includes areas where activities such as hunting and the construction of new buildings are forbidden. The activities concerning agriculture, woodlands, pasture, as well as fishing and the harvesting of natural products (edible plants, mushrooms, truffles etc.) are allowed, with some restrictions and rules, in all the territories included in the " $\mathrm{C}$ " area-called Protection Area-whereas in the " $\mathrm{D}$ " area economic activities are permitted when compatible with the MNP's mission and objectives, especially if aimed at improving the social and cultural life of local populations and visitors' enjoyment.

Collecting rocks, fossils and minerals is forbidden in the whole area of the MNP. Under specific conditions, researchers can obtain a temporary authorization to pick them. For fossil collection it is also necessary to obtain the permission of the archeological survey of Abruzzo (Soprintendenza Archeologia, Belle Arti e Paesaggio dell'Abruzzo, in short, SABAP Abruzzo), with which the MNP cooperates since 2001. Mining activities are also forbidden in the whole area of the MNP. The park's Carabinieri corps is in charge of surveillance in the MNP, through the coordination of the local board located in Guardiagrele $(\mathrm{CH})$. They operate to ensure that MNP's rules are observed. 


\section{The Geological Heritage of the Area}

\subsection{Geological and Geomorphological Framework}

The MNP is located in the central Apennines (Figure 1). The core part of the park coincides with the Majella Massif, an arc-shaped asymmetrical anticline gently plunging towards the NW and SSW. In correspondence of the fold axis culmination, an alignment of carbonate peaks exceeding 2500 meters in elevation is spectacularly exposed. To the west the MNP includes the NNW-SSE trending high reliefs of the Morrone, Porrara, Pizzalto and Rotella Mountains and south-east the relatively less high reliefs of the Pizzi-Secine Mts.

Looking at the geological aspect, the territory of the MNP is one of the most interesting regions of the central Apennines, where geology is quite complex but exposures are superb and subsurface features well-known among the scientific community. A prominent geological lineament running NE-SW, from the south-eastern foot of Majella to the Pizzalto-Rotella Mts., divides the territory of the park into two regions characterized by different structural architectures (Figure 3). The area to the west of this lineament, which corresponds to almost all of the entire territory of the MNP, is a mountain chain constituted by an imbricate fan of thrust sheets transported piggy-back towards the Adriatic between the latest Messinian (about 5.5 Ma) and the early Pleistocene (1.8 Ma). These thrust sheets, grouped in two major tectonic units (Morrone-Porrara Unit and Majella Unit), are made up of the Mesozoic-Tertiary platform-and-basin-derived carbonate sequences capped by siliciclastic flysch deposits. Mesozoic shallow-water carbonates characterize the southern portion of these units whilst basinal cherty limestones characterize the northern portion. Sedimentary structures and fossil content recovered in the shallow-water carbonates attest a long period of sedimentation in warm, shallow-marine environments, revealing that the Majella and surrounding carbonate massifs looked, at least from about 140 to about 7 million years ago, as the present-day Bahamas and Persian Gulf.

A spectacularly exposed platform-to-basin transition, with very well preserved paleoslope and adjacent talus breccia, progressively filling the proximal areas of the basin, crops out in the central part of Majella (Figure 4) and is widely described in international scientific papers [16-18]. The overlying flysch deposits, Messinian (from 6.4 to about 5.5 Ma) in age in the western unit (Morrone-Porrara Unit) and lower Pliocene (from 5.3 to about $4 \mathrm{Ma}$ ) in the eastern one (Majella Unit), indicate the progressive forward migration of the thrust belt-foredeep system towards the Adriatic foreland. The area to the south-east of the prominent structural lineament, represented in the MNP by the Pizzi-Secine Mts., belongs to the Molise Nappe, a rootless stack of basin-derived allochthonous sheets which tectonically overlies the lower Pliocene flysch of Majella. The Molise Nappe consists of a thick pile of Mesozoic-Tertiary basinal limestones and siliciclastic deposits that, in the area of the park, lies over the Majella unit in correspondence of its southern termination.

The complex geological history of the Majella Massif and surrounding areas closely matches the unusual geomorphological heterogeneity of the territory. In fact, a variety of different landforms, resulting from a combination of karst, glacial and fluvial processes, characterizes the MNP. Bare pitted highlands shaped by flowing ice that covered the higher parts of the massif long ago, similar to lunar landforms, characterize the top of the Majella (i.e., Femmina Morta Valley). Impressive narrow canyons (i.e., Inferno Valley) sided by vertical cliffs cut across the Majella exposing thick sequences of basinal and platform-derived carbonates. Wide sunny karstic plateaux covered by Holocene lacustrine deposits, younger than 10,000 years, (i.e., Quarto di Santa Chiara at $1250 \mathrm{~m}$ a.s.l.; Figure 5) are interposed between the NW-SE elongate reliefs of Rotella, Pizzalto and Porrara.

Woodlands rich in water characterize the wide tectonic depressions like that of the Caramanico Valley (carved by the Orta River) which separates the rounded gentle profile of the Majella Massif (Figure 6) from the impervious steep slope of the Morrone. Finally, an area with gently sloping mountains rich in woods and water (Secine-Pizzi Mountains), ideal shelter for many rare wildlife species, borders on the south of the Majella Park. 


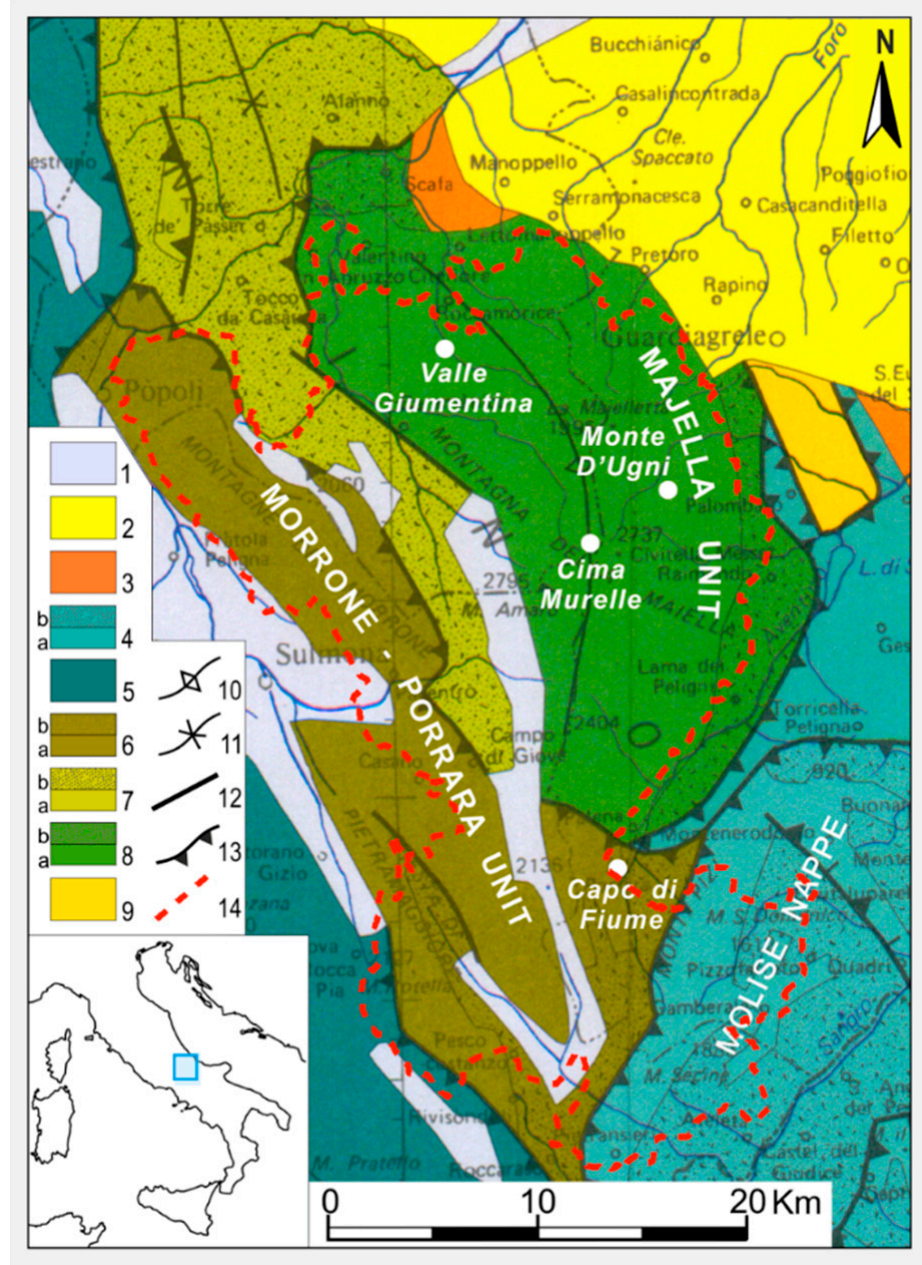

Figure 3. Simplified geological-structural map of the Majella and surrounding areas showing the areal distribution of the recognized tectonic units. 1: continental deposits (middle Pleistocene p.p.-Holocene); 2: marine and subordinate continental deposits post-dating the nappe transport (lower Pleistocene-middle Pleistocene p.p.); 3: marine and paralic thrust-top deposits (Pliocene); 4: Molise Nappe (b: uppermost Tortonian-Messinian p.p. siliciclastic flysch deposits, a: Jurassic-Tortonian p.p. basinal carbonates); 5: Gran Sasso-Genzana Unit; 6: Morrone-Porrara Unit (b: Messinian p.p. siliciclastic flysch deposits, a: Jurassic-Messinian p.p. platform-to-basin carbonates); 7: Queglia Unit (b: Messinian p.p.-lower Pliocene p.p. siliciclastic flysch deposits, a: upper Cretaceous-Messinian p.p. platform-to-basin carbonates); 8: Majella Unit (b: lower Pliocene siliciclastic flysch deposits, a: lower Cretaceous-Messinian platform-to-basin carbonates and evaporites); 9: Casoli-Bomba Unit (Pliocene hemipelagic clays); 10: anticline axis; 11: syncline axis; 12: normal faults; 13: low-angle thrusts; 14: boundary of the MNP Park. Modified after [16].

Thanks to its peculiar setting (high reliefs not far from the sea), unique in the European framework, and to the wide geomorphological heterogeneity, the park is characterized by a great variety of microclimates, ecosystems and ecological niches, which has allowed a precious and rare heritage of biodiversity to develop and be preserved. One third of the entire Italian flora (including numerous endemic species) and several rare wild animals are preserved within the MNP.

The park also preserves evidence of how much the geomorphologic features can be deeply fused with cultural inheritance. The first human presence in the area dates back to the Early Paleolithic (about 600,000 years ago), as testified by the stone tools recovered in lacustrine deposits at Giumentina Valley Site (730 m a.s.l.) which is one of the oldest human settlements of Western Europe [19-30]. 115 [31] 
are the karstic caves currently known within the MNP, many of which are of significant archeological interest. Together with the steep calcareous slopes of the MNP, they were also preferred by hermits as places of solitude and asceticism. Since the medieval period and until the last century many human activities, such as agro-pastoral practices and mining, left evident signs on the landscape and are strictly linked to geological features and resources of the territory.

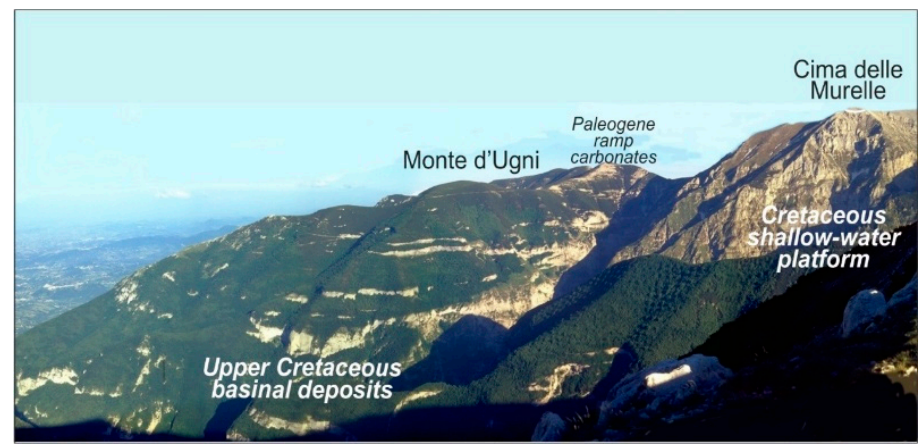

Figure 4. Panoramic view on the Upper Cretaceous platform-to-basin depositional system of central Majella. Figure 3 shows the location of the Monte d'Ugni and Cima Murelle Mts. Photo: E. Patacca Scandone.

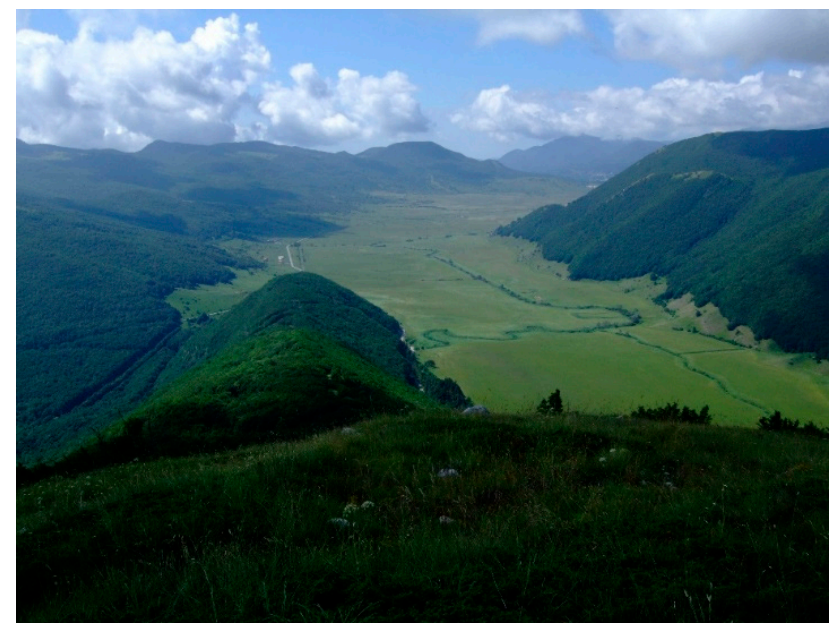

Figure 5. The karstic plateaux covered by Holocene (0.01 Ma) lacustrine deposits of Quarto Santa Chiara, located at $1250 \mathrm{~m}$ a.s.l. In the photo are clearly recognizable the La Vera Stream meanders. Photo: MNP Archive/L. Di Martino.

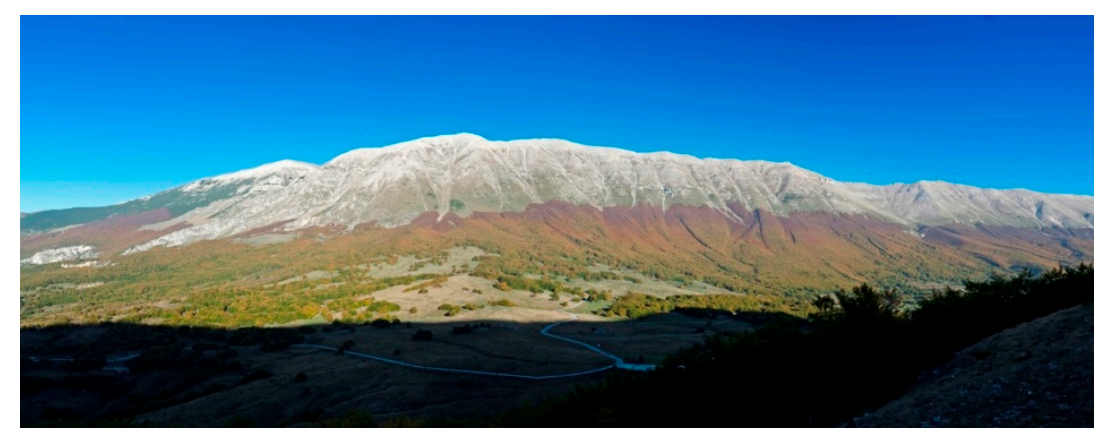

Figure 6. The northern and western side of the Majella Massif with its main peak Mt. Amaro (2793 m a.s.l.). Photo: MNP Archive/L. Del Monaco. 
Every year several Italian and foreign researchers visit the MNP for their scientific programs and educational field trips. Owing to the well-preserved platform-to-basin carbonate depositional system, the Majella Mountain acts in fact as a model for hydrocarbon genesis and oil migration.

\subsection{Geosite Database and Case Studies}

It is understandable that in the framework just outlined many dozens of interesting sites are worthy to become geosites. Following the criteria briefly illustrated above, more than 95 geosites were recorded in the GD of the aspiring Geopark and a new map was elaborated (Figure 1). Some of the geosites included in the GD (22 in total) are well-known in the international geological and palaeontologic literature because of their scientific relevance. The most part are geomorphosites, the majority of which consist in karst and glacio-karst landforms, with one rare example of tropical karst, then the most representative are the stratigraphy and sedimentology type, followed by the Quaternary geology and archaeology type (Figure 7). Almost three quarters of them are of international or national relevance (Figure 8a). Among sites with an international stratigraphic interest, the most prominent is the Decontra key section which allows correlation of Mediterranean shallow water deposits with global Oligocene-Miocene stratigraphy [32-44]. Last, but not least, palaeontological, hydrogeological and structural geology geosite types are to be mentioned. Even if just 3 sites belonging to the hydrocarbon genesis and migration type and the mining and industrial archaeology type have been recorded up until now in the MNP GD, they represent a peculiarity of the aspiring Geopark. Thanks to the recent increasing interest for the former Majella Mining Bitumen Complex [45-61] from both researchers and institutions, their number is expected to rise. The MNP GD format also furnishes the value of each geosite (Figure $8 \mathrm{~b}$ ) in geoturistic, educational and scientific terms. A site could be included in all the mentioned categories.

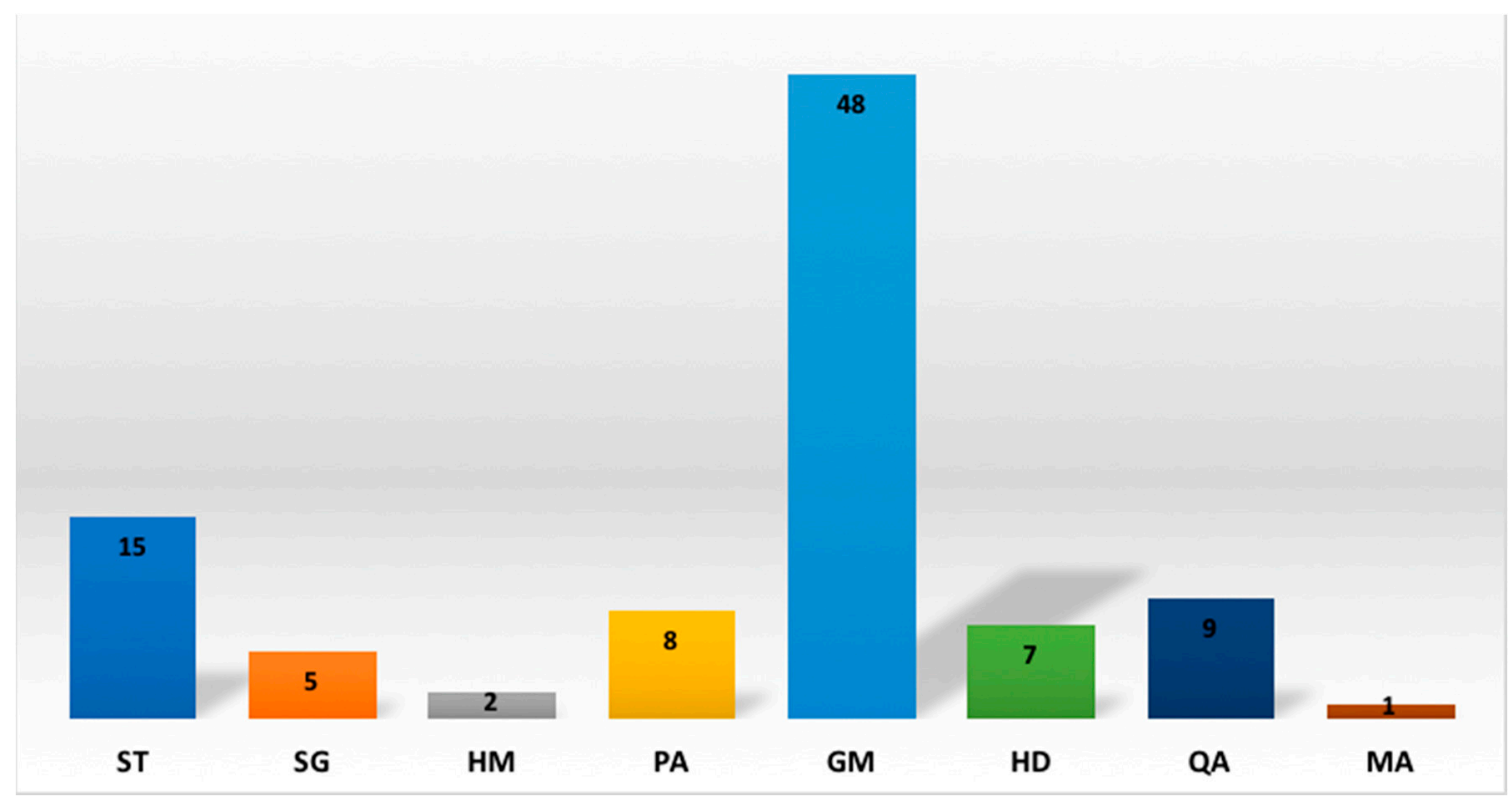

Figure 7. The main interest (TYPE) of the geosites in the Majella aspiring Geopark. Legend: Stratigraphy and sedimentology (ST); Structural geology (SG); Palaeontology (PA); Geomorphology (GM); Hydrology and hydrogeology (HD); Quaternary geology and archaeology (QA); Mining and industrial archaeology (MA); Hydrocarbon genesis and migration (HM). 


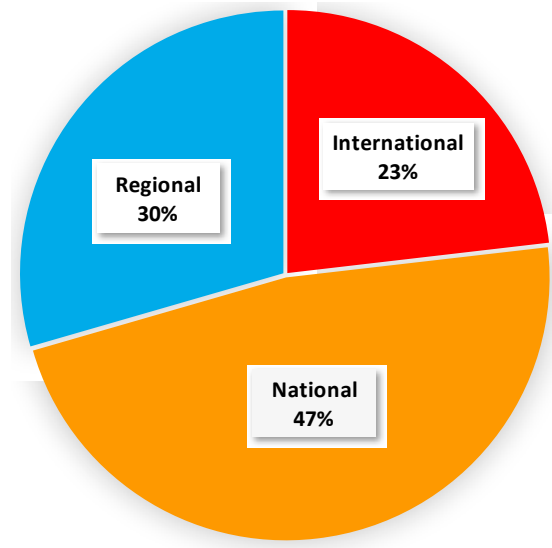

(a)

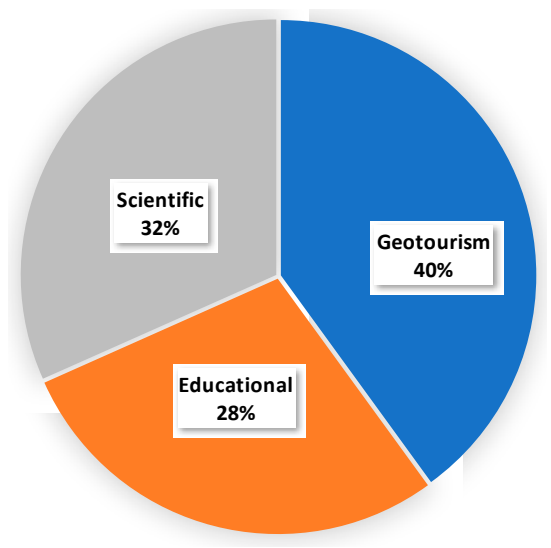

(b)

Figure 8. The RELEVANCE (a) and the VALUE (b) in \% of the geosites in the Majella aspiring Geopark area.

The most prominent example of these "multi-valued" geosites is surely the fossil field of Capo di Fiume [62-68] (Figure 9), which is visitable since 2001 thanks to some facilities (wood fence, educational panels, picnic area). It is connected to the Alto Aventino Geopalaeontologic Museum (Figure 10), sited inside the Ducal Castle of the nearby village of Palena, one of the MNP municipalities. Other important international geosites are the aforementioned archeogeosite of the Giumentina Valley [19-30], the so-called "Petroleoum Springs" of Tocco da Casauria [47,48,50-52,54-61], the groundwater-fed springs of Verde $[50,69,70]$ and the Nera Cave with abundant moonmilk concretions $[71,72]$.

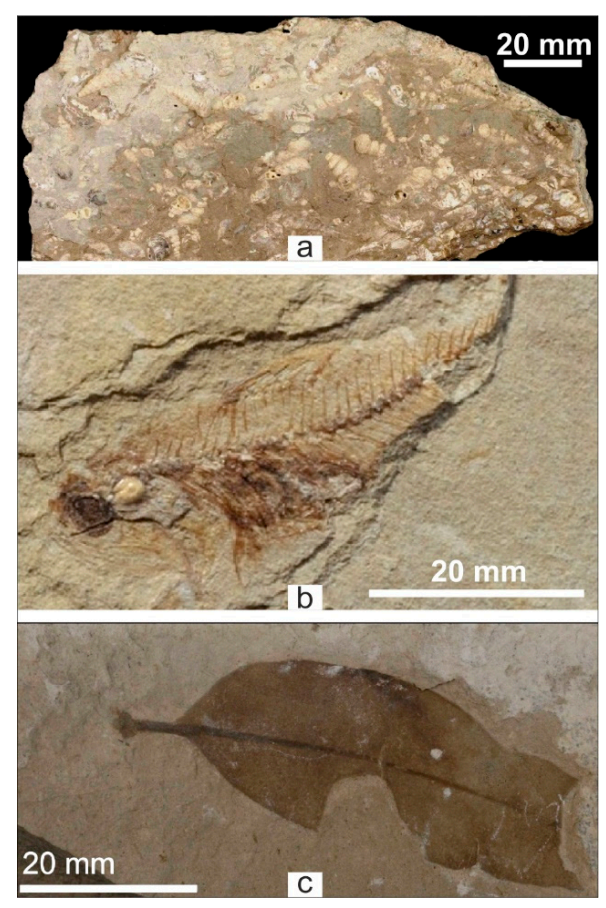

Figure 9. Fossils from Capo di Fiume stratigraphic section (see location in Figure 4): (a) lumachella layer containing Dreissena, potamidids, cerithiids, litiopids, and diastomids indicative of Messinian estuarine-bay deposits; (b) fish remains of Diaphus edwardsi from laminated diatomitic layers; (c) leafd from diatomitic marls. Photo: G. Carnevale. 


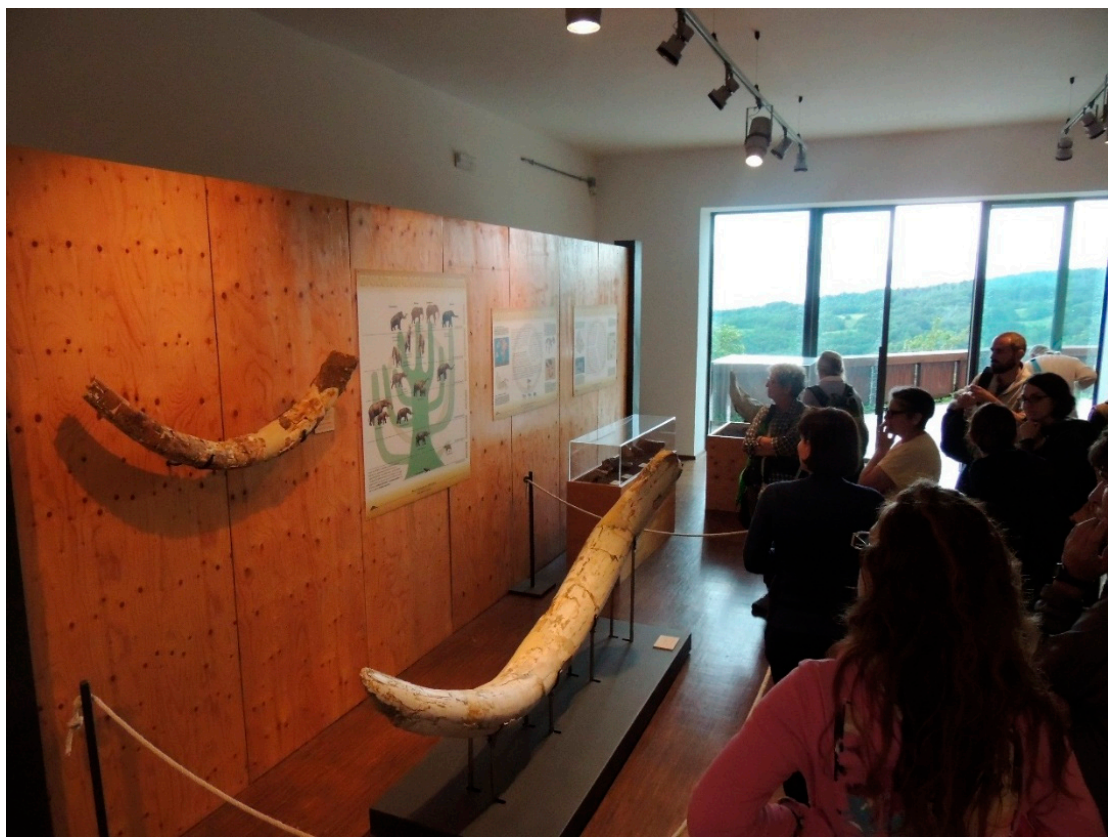

Figure 10. The Alto Aventino Geopaleontogical Museum housed in the Ducal Castle of Palena. The photo shows some fossil findings from the hilly area facing eastern Majella (defenses of Mammuthus meridionalis). Photo: MNP Archive/M. Spera.

In Table 1, a comparison between the Majella and Ruban types of geosites [9] based on the effective presence of the latter within the aspiring Geopark territory, is illustrated. Considering that in the GD complex geosites have not yet been identified for the reasons previously discussed, at least two other Ruban types, namely mineral and pedological (soil), could be added to the list. Therefore, there are $13(11+2)$ geosite types occurring in the aspiring Geopark territory. However, with some differences, the MNP GD types match quite well with part of the 21 types of geosites distinguished by [9]. Some differences are due to the intention to fit better to MNP geological features and to the goals of the application dossier for the UNESCO GGN. For example, geomorphological sites are the most represented in the area and need to be further detailed (i.e., 8 resulting subcategories in MNP dossier vs. 3 listed by Ispra [14] and 3 by [9]). In order to manage this issue, the keyed classification of natural geodiversity for land management and nature conservation purposes of [11] could be considered. However, in this phase of the work, it is premature to assess this kind of evaluation which deserves a separate work and discussion.

Table 1. Comparison between Majella and Ruban [9] types of geosites based on the effective presence within the aspiring Geopark.

\begin{tabular}{llc}
\hline \multicolumn{1}{c}{ Majella } & \multicolumn{1}{c}{ [9] } & Presence of Ruban Type \\
\hline Stratigraphy and sedimentology (ST) & Stratigraphical & Yes \\
& Sedimentary & Yes \\
Palaeontology (PA) & Palaeontological & Yes \\
Industrial archaeology (MA) & Economic & Yes \\
Hydrocarbon genesis and migration (HD) & & \\
Structural geology (SG) & Structural & Yes \\
& Neotectonic & Yes \\
Quaternary geology and archaeology (QA) & Palaeogeographical & Yes \\
Geomorphology (GM) & Geomorphological & Yes \\
& Geocryological & Yes \\
Hydrology and hydrogeology (HD) & Engineering & Yes \\
\hline
\end{tabular}


According to [8]:

Geodiversity 1 = Total quantity of geosite types occurring on a given territory

Consequently, the Geodiversity score for the Majella aspiring Geopark is 13.

At the same time, we evaluated the Geoabundance [8] which is defined as follows:

Geoabundance $1=$ Total quantity of geosites on a given territory

The Geoabundance score for the Majella aspiring Geopark is 95.

Considering that 8 of the total amount of geosites in the GD could be associated to other sites if considered as complex geosites [8], the geoabundance score drops to 87. At the moment, we have not yet identified any complex geosites [8] during this first census of geosites in the Majella aspiring Geopark area.

The evaluated scores for Geodiversity and Geoabundance could increase when achieving a complete inventory of MNP geosites, that is beyond the goals of the present work as already mentioned.

\section{Tourist Activities and Facilities}

In the aspiring Geopark there is a hiking network about $720 \mathrm{~km}$ long, which is complemented by numerous secondary roads suitable for mountain-biking (MTB) and horse riding. The MTB trails extends for about $426 \mathrm{~km}$, while the horse trails are overall $400 \mathrm{~km}$ long. The excursion trails are diversified for people of all skill levels, from very experienced hikers to families with children. This framework is completed by several non-managed bivouacs and refuges of different sizes, suitable for temporary recovery, emergencies or short stays, and some managed refuges, like "Rifugio Pomilio" on the eastern side of Majella and "Rifugio Paolo Barrasso" in the northern part of the Majella Massif. The network of trails and refuges is in direct connection with other MNP facilities and structures scattered throughout the territory.

Currently the park can count on 12 info points, 4 visitor centres (three of which host a museum), 1 museum, 2 botanical gardens and 7 wildlife areas (Figure 8). These structures are either directly managed by the park or outsourced to local associations and cooperatives, often composed of young people. Five of these structures are proper Environmental Education Centres (ECC) and obtained the recognition of "CEA di interesse regionale" (EEC of regional interest) from Region Abruzzo according to the regional Law 122/99, while another one is soon to obtain the same title. A network of park centers and structures exists and has been operating for almost two decades. Some of them pre-exist the MNP's institution, as visitor centers of the former natural reserves are currently part of the park. Some museums, managed from other local and regional entities and organizations, are closely linked to this network. There are numerous activities that one can choose to do in the aspiring Geopark: hiking and nordic-walking (with or without guided tour), MTB riding or horse riding, country cross-skying, snowshoeing, skiing and snowboarding (where it is allowed and infrastructure is present), climbing (where permitted), mountain running, orienteering, tree climbing (where infrastructure is present), environmental education activities, birdwatching, naturalistic or geological trips and excursions, picnicking and camping in equipped areas. Among these, there are also visits to the Cavallone Cave, a well-known cave with more than 10,000 visitors per year, and to the Scura Cave, which can only be accessed with the park' authorization. Caving is allowed under a specific authorization to speleological groups. In the park area there are also some spas. The most famous and frequented are the Caramanico spas where one can benefit from sulphourus thermal waters and other mineral waters. Just outside the aspiring Geopark's boundaries, other outdoor activities such as canyoning are practiced. Added to the above listed activities are handicraft laboratories and workshops to watch or attend, tasting of local food and beverage in restaurants, bakeries, wineries and even breweries, as well as shopping. Finally, the park offers the possibility for people passionate about nature to attend voluntary field-trips and try out typical park activities as volunteers alongside geologists, botanists, zoologists, veterinarians, environmental educators and other technical members of its staff. 


\subsection{Main Park's Visitor Centres Available for Geotourists}

The "Paolo Barrasso" Visitor Centre, the venue of the homonym CEA (ECC), is the ideal starting point for excursions in the Orfento Valley. It houses a small museum with a naturalistic section set up with show cases dedicated to the geology and fossils of Majella, a model of the Majella and Morrone with the Orta Valley among them, that allow for an appreciation of the geomorphology of the area, and reconstructions of the otter habitat. The main habitats of the Orfento Valley, such as beech, cliffs and Mugo pine formations, are also explained with panels and showcases. Very fascinating for children is the burrow of the otter. Upstairs there is an archaeological section with numerous artifacts found in the northern part of the Majella Massif, dated from the lower Paleolithic to the Roman era. In particular, there is some information on the Giumentina Valley, an archaeological and geological site of international importance. The archaeological section can also be accessed by people with motor disability and by blind and visually impaired visitors. Near the visitor centre there is the European otter wildlife area. Close to the centre there are also a library and a conference room, itself hosting another well-stocked library. The centre faces another structure called "Casa del Lupo" equipped with a conference room, a space for temporary exhibitions, as well as a guesthouse mainly open for scholars and university students, schools, park collaborators, volunteers and educational nature camps. The guest house has 25 beds, distributed in 13 rooms with a private bathroom, and it is equipped with a kitchen and a dining room. The same structure hosts the scientific offices of the MNP with some employees.

Another visitor centre is located in Fara San Martino, which is venue of the CEA (ECC) "La Porta del Sole". From this Centre, it is possible to visit the so called Fara Valley which, with its $14 \mathrm{~km}$ of length, which is among the longest canyons in Italy. It is also possible to reach the San Martino in Valle Monastery and the Verde river springs, which together with the San Martino narrow canyon and an important outcrop of Rudistes, constitute a highly valued but easy enough to access group of geosites. Inside the centre, which is located in the historical core of Fara San Martino, there is an interesting naturalistic museum with show cases about typical habitats, flora and fauna of the eastern Majella Massif, especially of the gorges environment. Several panels and showcases are dedicated to Majella geological history and geomorphology, including a collection of rock samples and fossils. There are also some reconstructions illustrating the life of the shepherds who, in the past, used to frequent the area. The structure is also equipped with a scientific educational laboratory dedicated to schoolchildren and researchers, a small guest house, and a scientific library.

The "Maurizio Locati" naturalistic-archaeological museum, located inside the Lama dei Peligni Visitor Centre, venue of the homonym CEA (ECC), hosts a large section dedicated to the Apennine Chamois set up with educational panels and dioramas illustrating the environment of the park's rock fauna. Here there is a small geological section which clearly explains the geological evolution of the Majella Massif from the Cretaceous to the Quaternary, and includes an exhibition of some representative rock samples and fossils. Alongside this exhibition, there is a diorama of the Caprara Cave where rock paintings from the Prehistoric Era have been found. A model shows the whole territory of the aspiring Geopark with its municipalities and allows visitors to have an overview of both geographical and geomorphological features of the protected area. On the upper floor, there is also an interesting archaeological section that allows one to retrace the history of the eastern Majella from the present days, back to the Middle Ages, the Romans and Prehistory. Among the most ancient finds, there is the skull of the so-called "Man of Majella", found in Fonterossi near Lama dei Peligni, dating back over 7000 years ago. Here are also preserved the Pleistocene palaeontological findings of various mammals from the Orsi Volanti Cave located in Rapino, one of the geosites of the aspiring Geopark. An additional showcase with fossil findings of the same origin and period is going to be implemented soon in the museum. Close to the centre, and adding to the aforementioned visitor attractions, there are the "Michele Tenore" Botanical Garden, with about 500 plant species inserted in flowerbeds that show the various habitats of the eastern Majella, the Germoplasm Bank of the Majella, aimed at preserving rare, endemic and endangered botanical species, and the Neolithic Village 
(reconstruction). An indoor conference hall and an open-air auditorium overlooking the Majella, a bookshop, and a small library complete the structure. The visitor centre is also connected to the wildlife area of the Apennine Chamois. The structure hosts some of the offices of the Park Authority where several of its staff members are located too.

\subsection{Other Relevant Museums}

Inside or just outside the aspiring Geopark boundary, there are several other noteworthy museums which allow geotourists to complete the visit. Particularly important are those that are strongly linked to geology and geosites of the aspiring Majella Geopark. These are the Alto Aventino Geopalaeontological Museum in Palena (Figure 10), the Museum of Ambers and Fossils in San Valentino in A.C., the Cavallone Easy virtual museum in Taranta Peligna, the Paleolithic Ecomuseum at the Giumentina Valley (Abbateggio) and the Nature History Museum of Sulmona which hold a wide collection of minerals. There are also two archaeological museums located in Juvanum di Montenerodomo and in Guardiagrele, as well as various installations dedicated mainly to the history, culture and local traditions that often have a strong connection with the availability of raw materials and natural resources of the area due to its geological features.

The Alto Aventino Geopalaentological Museum, housed in the Ducal Castle of Palena, is surely the most peculiar. It is a unique visit system together with the aforementioned palaeontological and stratigraphic site of Capo di Fiume and the facing hydrologeological site of the Aventino springs. Inaugurated in 2001, it is the result of a fruitful collaboration between different institutions (the SABAP Abruzzo, the Municipality of Palena and the Province of Chieti). The system bears the logo of the MNP (the aspiring Geopark) as it cooperates with the others to settle and maintain the geosites' infrastructure. The museum holds the fossil collection from Majella by Erminio Di Carlo with rare and important fish remains of about 7 million years ago, unique plant remains and the famous Prolago, a small terrestrial Upper-Miocene mammal. Most findings come from the Porrara slopes, and are therefore from the eastern sector of the Geopark. Inside the museum, there are also fossil findings from the nearby town of Torricella Peligna and some more recent specimens of mammals that have inhabited the hills in front of the Majella. The museum starts with an educational section on general geology and palaeontology and has a space called "Geologiocando" with activities for children. Standing outside the terrace called the "Geological Observatory" visitors can appreciate the amazing panorama of the Majella Massif, the Mt. Porrara, the Pizzi Mts., and of the Aventino Valley enjoying the geological-geomorphological peculiar landscape of the area. The museum has a conference room too.

\section{Discussion and Conclusions}

Geology and natural and cultural heritage are deeply fused in the MNP. Many habitats have a strong geological connotation. Those listed in annex I of the European Community Habitat Directive, linked to rocky and scree bare grounds, are: 8130 "Western Mediterranean and thermophilous screes", 8120 "Calcareous and calcshist screes of the montane to alpine levels (Thlaspietea rotundifolii)", 8210 "Calcareous rocky slopes with chasmophytic vegetation", 8240 "Limestone pavements", 8310 "Caves not open to the public". The latter hosts important European species of Chyroptera. The 8240 is even a priority natural habitat. The combination of geographical, lithological, geomorphological and climatological peculiar features of the aspiring Geopark have allowed the existence of more than 2250 botanical entities, more than 40 species of mammals, several hundred bird species, about 30 species of reptilians and amphibians, and thousands of invertebrates.

The first human presence in the area dates back to the Early Paleolithic layers of the Giumentina Valley (600,000 years ago), one of the oldest settlements and archeogeosites in Europe. Many caves have been frequented by humans since the Prehistoric Era, while steep rocky slopes and deep gorges hosted monasteries and hermitages during the Middle Ages (Figure 2). In the last centuries, pastoral, agricultural and mining activities left evident signs on the landscape. Even second world war events in the area are closely linked to the geological and geomorphological features of the territory. 
The geosites of the aspiring Geopark currently identified and listed, in total 95, satisfy people at any level of interest from scholars and schools, to simply geology amateurs. In fact, other than the accepted scientific and educational value of its geological heritage, the aspiring Geopark can count on other strong points: its short distance from Rome; internal, quite good road connections; a long network of trails for hikers, MTBs and horse riders; and the experienced network of info points, visitor centers, museums, environmental education centers, already operating for decades. Among the aims of the MNP authority is to catalogue and include all the data concerning its geosites in the Ispra Geosite Inventory. The main goal, however, is to make these geosites known to the public, including local administrators, tourist operators, guards, inhabitants and geotourists. In fact, there are many natural and anthropic threats that can compromise the integrity of a geosite. The mere knowledge of their existence and importance is the first step for removing any risk of losing the site forever or of compromising its fruition. Although with some differences, the MNP GD types match quite well part of the 21 types of geosites distinguished in [9]. In the following steps of the candidature process, we consider refining the classification used for the Majella aspiring Geopark GD and comparing it with the classification proposed in $[9,11]$.

For the reasons discussed above, the Park Authority, supported by the regional association of professional geologists (OGRA-Ordine dei Geologi della Regione Abruzzo), decided to put its territory forward as a candidate of the UNESCO Global Geoparks Network. Other partners of the project are: the regional archeological survey (SABAP Abruzzo), the Region Abruzzo, its provinces and municipalities, as well as other local stakeholders, and the national speleological society (SSI-Società Speleologica Italiana). The Park Authority, which already has similar experiences in international contexts, firmly believes in cooperation among geoparks which share the same goals and that are strongly characterized by real geological heritage, as a "cradle" for plants, animals and humans. It is certain that, in case of recognition, sharing experiences and good practices through the aforementioned network will promote mutual knowledgment and peaceful coexistence among peoples, and will lead to the application of advanced and effective strategies of sustainability in the economic, social and environmental fields.

Author Contributions: Conceptualization, E.L. and G.B.; Methodology, E.L. and A.G.; Formal Analysis, A.G.; Investigation, E.L., G.B., S.A., A.G., E.P.S.; Data curation, E.L.; all the authors contribute substantially to the Writing-Original Draft Preparation, in particular: A.G. and E.L. for introduction, materials and methods; E.L. for general features of the Majella Aspiring Geopark; E.P.S. for geological and geomophological framework; E.L., A.G., S.A. and G.B. for MNP Geosite Database; E.L. and S.A. for tourist activities and facilities in the Majella Aspiring Geopark; Writing-Review \& Editing, E.L. and A.G.; Visualization, E.L., A.G. and E.P.S.

Acknowledgments: The authors are grateful to all the geologists of the Ordine dei Geologi della Regione Abruzzo who contributed to the project of candidacy of MNP as a UNESCO Geopark, in particular to President Nicola Tullo and to the Geosites and Geopark Commission. Special gratitude goes to the former President of the MNP's Authority Franco Iezzi, who firmly believed in the project since the beginning, as well as to the Director Arch. Oremo Di Nino and to the Vice-President Geom. Claudio D'Emilio. Many thanks to all MNP staff members who are cooperating to the project in different ways, in particular to Maria Peroni, Giuseppe Marcantonio, Giampiero Ciaschetti and Mariano Spera, who directly contributed to the present paper. Authors also thanks Marco Brandano and Elisa Nicoud who collaborated in the identification and description of some geosites. Special thanks go to the members of the Geopark National Committee, Aniello Aloia, Cristina Giovagnoli and Maurizio Burlando for their support during the whole application process.

Conflicts of Interest: The authors declare no conflict of interest.

\section{References}

1. Wimbledon, W.A. L'identificazione e la selezione dei siti archeologici, una priorità per la geoconservazione. In Geositi Testimoni del Tempo. A Cura di Giancarlo Poli; Edizioni Pendragon: Emilia-Romagna, Italy, 1999.

2. IUGS-Heritage Sites and Collections Subcommission (HSCS). Available online: https://geoheritage-iugs. mnhn.fr (accessed on 9 July 2018).

3. Gray, M. Geodiversity: Valuing and Conserving Abiotic Nature; Wiley Blackwell: Chichester, UK, 2013.

4. Henriques, M.H. Jurassic Heritage of Portugal: State of art and open problems. Rivista Italiana di Paleontologia e Stratigrafia 2004, 110, 389-392. 
5. UNESCO Global Geoparks Network. Available online: http://www.unesco.org/geoparks (accessed on 9 July 2018).

6. Gisotti, G.; Burlando, M. The Italian job. Earth Herit. 1998, 9, 11-13.

7. Henriques, M.H.; Brilha, J. UNESCO Global Geoparks: A strategy towards global understanding and sustainability. Episodes 2017, 40, 349-355. [CrossRef]

8. Ruban, D.A. Quantification of geodiversity and its loss. Proc. Geol. Assoc. 2010, 121, 326-333. [CrossRef]

9. Ruban, D.A.; Kuo, I. Essentials of geological heritage site (geosite) management: A conceptual assessment of interests and conflicts. Nat. Nascosta 2010, 41, 16-31.

10. Ruban, D.A. Geodiversity as a precious national resource: A note on the role of geoparks. Resour. Policy 2017, 53, 103-108. [CrossRef]

11. Bradbury, J. A keyed classification of natural geodiversity for land management and nature conservation purposes. Proc. Geol. Assoc. 2014, 125, 329-349. [CrossRef]

12. Habibi, T.; Ponedelnik, A.A.; Yashalovac, N.N.; Ruban, D.A. Urban geoheritage complexity: Evidence of a unique natural resource from Shiraz city in Iran. Resour. Policy 2018. [CrossRef]

13. Agostini, S.; De Flaviis, A.G.; Rossi, M.A. La Regione Abruzzo: Attività di censimento, tutela e valorizzazione. In Patrimonio Geologico e Geodiversità. Esperienze ed Attività dal Servizio Geologico d'Italia all'APAT; APAT: Roma, Italy, 2005.

14. Ispra Geosite Inventory Format. Available online: http://sgi.isprambiente.it/geositiweb/public/scheda_ geositi.pdf (accessed on 9 July 2018).

15. Ispra National Inventory of Geosites. Available online: http://www.isprambiente.gov.it/en/projects/ soil-and-territory/protection-of-geological-heritage-parks-geomining-geoparks-and-geosites/nationalinventory-of-geosites?set_language=en (accessed on 9 July 2018).

16. Patacca, E.; Scandone, P. Geology of the Southern Apennines. In Results of the CROP Project, Sub-Project CROP-04 Southern Apennines (Italy); Mazzotti, A., Patacca, E., Scandone, P., Eds.; Bollettino della Società Geologica Italiana: Roma, Italy, 2007.

17. Eberli, G.P.; Bernoulli, D.; Sanders, D.; Vecsei, A. From aggradation to progradation: The Maiella platform, Abruzzi, Italy. In Cretaceous Carbonate Platforms; Simo, T., Scott, R.W., Masse, J.P., Eds.; AAPG: Tulsa, OK, USA.

18. Carnevale, G.; Patacca, E.; Scandone, P. Field Guide of the Post-Conference Excursions (Scontrone, Palena and Montagna della Majella). Available online: https://www.academia.edu/8938470/Field_Guide_of_the_ Post-Conference_Excursions_Scontrone_Palena_and_Montagna_della_majella_4-5_March_2011._Intern. _Conference_Neogene_Park_Vertebrate_Migration_in_the_Mediterranean_and_Paratethys._R.C.M.N.S. _Interim_Colloquium_1-3_March_2011_Scontrone_L_Aquila_Italy_(accessed on 10 July 2018).

19. Demangeot, J.; Radmilli, A.M. Le Gisement Quaternaire de la Valle Giumentina (Abruzzes Adriatiques)— Stratigraphie et Palethnologie; Consiglio nazionale delle ricerche: Roma, Italy, 1954.

20. Demangeot, J. Géomorphologie des Abruzzes adriatiques. In Centre Recherche et Documentation Cartographique, Memoires et Documents; CNRS: Paris, France, 1965; p. 403.

21. Demangeot, J.; Mario Radmilli, A. Le gisement paléolithique de Valle Giumentina (Apennin central) et ses problèmes. E G Quat. Sci. J. 1966, 171, 12-15.

22. Limondin-Lozouet, N.; Villa, V.; Pereira, A.; Nomade, S.; Bahain, J.-J.; Stoetzel, E.; Aureli, D.; Nicoud, E. Middle Pleistocene Molluscan Fauna from Central Italy at Valle Giumentina (Abruzzo): Palaeoenvironmental, biostratigraphical and biogeographical implications. Quat. Sci. Rev. 2017, 156, 135-149. [CrossRef]

23. Nicoud, E.; Agostini, S. Livret-Guide de L'excursion, AFEQ CNF INQUA 2016; EFR-CEPAM-Parco nazionale della Majella: Valle Giumentina, Italy, 2016.

24. Nicoud, E.; Aureli, D.; Pagli, M. Valle Giumentina (Abruzzes, Italie), Quatrième Mission: Étude des Comportements Techno-Économiques au Pléistocène Moyen; Persée: Lyon, France, 2016.

25. Nicoud, E.; Aureli, D.; Pagli, M. Comportements techniques au Pléistocène moyen en Italie: Nouvelles recherches sur l'industrie lithique et le site de Valle Giumentina (Abruzzes). Mélanges de l'École Française de Rome Antiquité 2015, 127, 5-28. [CrossRef]

26. Radmilli, A.M. La Vita in Abruzzo Ventimila Anni fa-Il Paleolitico Superiore; Parco Nazionale della Majella; Edizioni ETS: Pisa, Italy, 1997; p. 275.

27. Radmilli, A.M. Primi Uomini in Abruzzo—Il Paleolitico Inferior; Opera postuma; Museo delle Genti D'Abruzzo; Tipografia SIGRAF: Pescara, Italy, 1999; p. 238. 
28. Villa, V.; Pereira, A.; Chaussé, C.; Nomade, S.; Giaccio, B.; Limondin-Lozouet, N.; Fusco, F.; Regattieri, E.; Degeai, J.-P.; Robert, V.; et al. A MIS 15-MIS 12 record of environmental changes and Lower Palaeolithic occupation from Valle Giumentina, Central Italy. Quat. Sci. Rev. 2016, 151, 160-184. [CrossRef]

29. Villa, V.; Virmoux, C.; Chaussé, C.; Degeai, J.-P.; Robert, V.; Kuzucuoglu, C.; Boschian, G.; Agostini, S.; Aureli, D.; Pagli, M.; Nicoud, E. The long sedimentary succession of the Valle Giumentina basin (Abruzzo, central Italy): New evidence from stratigraphic studies and electrical resistivity tomography (ERT). Alp. Med. Quat. 2016, 29, 193-199.

30. Villa, V.; Chaussé, C.; Nicoud, E.; Aureli, D.; Pagli, M. Valle Giumentina (Abruzzes, Italie). Nouvelles observations de la stratigraphie. Mélanges de l'École française de Rome Antiquité 2015, 127, 2-16.

31. Wish-Portale del Catasto Nazionale delle Grotte d'Italia. Available online: http://speleo.it/catastogrotte/ ricerche (accessed on 9 July 2018).

32. Brandano, M.; Scrocca, D.; Lipparini, L.; Petracchini, L.; Tomassetti, L.; Campagnoni, V.; Meloni, D.; Mascaro, G. Physical stratigraphy and tectonic settings of Bolognano Formation (Majella): A potential carbonate reservoir. Journal of Mediterranean Earth Sciences Pre-Congress Field trip guide. In Proceedings of the XI GeoSed Congress Italian Association for Sedimentary Geology, Rome, Italy, 22-28 September 2013; pp. 151-176.

33. Brandano, M.; Lipparini, L.; Romi, A.; Campagnoni, V.; Tomassetti, L. Downslope-migrating sand wave in the Chattian carbonate ramp of Majella (Central Apennines, Italy). Rend. Soc. Geol. Ital. 2011, 17, 29.

34. Crescenti, U. Stratigrafia della serie calcarea dal Lias al Miocene nella regione marchigiano-abruzzese (parte I-Descrizione delle serie stratigrafiche). Mem. Soc. Geol. Ital. 1969, 8, 155-204.

35. Crescenti, U.; Crostella, A.; Donzelli, G.; Raffi, G. Stratigrafia della serie calcarea dal Lias al Miocene nella regione marchigiano-Abruzzese (Parte II: Litostratigrafia, biostratigrafia, paleogeografia). Mem. Soc. Geol. Ital. 1969, 8, 343-420.

36. Di Napoli Alliata, E. Il Miocene superiore nella Valle dell'Orte presso Bolognano (Pescara). Geol. Rom. 1964, 3, 3-40.

37. Mutti, M.; Bernoulli, D. Early marine lithification and hardground development on a Miocene ramp (Maiella, Italy): Key surface to track changes in trophic resources in non tropical carbonate settings. J. Sediment Res. 2003, 73, 296-308. [CrossRef]

38. Mutti, M.; Bernoulli, D.; Spezzaferri, S.; Stille, P. Lower and Middle Miocene carbonate facies in the Central Mediterranean: The impact of paleoceanography on sequence Stratigraphy. In Advances in Carbonate Stratigraphy: Application to REsorvoirs, Outcrops and Models; SEPM: Broken Arrow, OK, USA, 1999; p. 63.

39. Mutti, M.; Bernoulli, D.; Stille, P. Temperate carbonate platform drowning linked to Miocene oceanographic events: Maiella platforms margin, Italy. Terra Nova 1997, 9, 122-125. [CrossRef]

40. Schiavinotto, F. Nephrolepidina morgani (Lemoine and R. Douvill, 1908) from the Oligo-Miocene of Decontra section (Majella, Central Apennines). J. Med. Earth Sci. 2015, 7, 19-33.

41. Reuter, M.; Piller, W.E.; Brandano, M.; Harzhauser, M. Correlating Mediterranean shallow water deposits with global Oligocene-Miocene stratigraphy and oceanic events. Glob. Planet. Chang. 2013, 111, 226-236. [CrossRef] [PubMed]

42. Vecsei, A. Aggradation und Progradation eines Karbonatplattfrom-Randes: Kreide bis Mittleres Tertiär der Montagna della Maiella, Abruzzen. Ph.D. Thesis, Mitteilungen aus dem Geologischen Institutes der Eidgenössisichen Technischen Hochschule und der Universität, Zürich, Switzerland, 1991; p. 169.

43. Vecsei, A.; Sanders, D.G.K. Facies analysis and sequence stratigraphy of a Miocene warm-temperate carbonate ramp, Montagna della Maiella, Italy. Sediment. Geol. 1999, 123, 103-127. [CrossRef]

44. Vecsei, A.; Sanders, D.G.K.; Bernoulli, D.; Eberli, G.P.; Pignatti, J.S. Cretaceous to Miocene sequence stratigraphy and evolution of the Maiella carbonate platform margin, Italy. In Mesozoic and Cenozoic Sequence Stratigraphy of European Basins; SEPM: Broken Arrow, OK, USA, 1998; Volume 60, pp. 53-74.

45. Agostini, S.; Colecchia, A. Economie marginali e paesaggi storici nella Maiella settentrionale (Abruzzo, Italia). Eur. J. Post. Class. Arch. 2014, 4, 219-258.

46. Aristone, O.; Di Loreto, A. L'attività Mineraria in Italia. Un'industria Chiusa, una Questione Aperta. Available online: https:/ / www.academia.edu/28284024/Lattivit\%C3\%A0_mineraria_in_Italia_unindustria_ chiusa_una_questione_aperta (accessed on 10 July 2018).

47. Capellini, G. Petrolio di Tocco e Bitumi di Letto Manopello. Regia Acc. Sci. Torino 1866, 3, 1-3. 
48. Conese, M.; Nanni, T.; Peila, C.; Rusi, S.; Salvati, R. Idrogeologia della Montagna del Morrone (Appennino Abruzzese): Dati preliminari. Mem. Soc. Geol. Ital. 2001, 56, 181-196.

49. Coppa-Zuccari, G. Le rocce asfaltiche abruzzesi. Loro impiego nelle costruzioni stradali e nella produzione di oli combustibili. Sci. Tecn. 1939, 3, 753-761, S.I.P.S.; Roma.

50. Desiderio, G.; Ferracuti, L.; Rusi, S.; Tatangelo, F. Il contributo degli isotopi naturali ${ }^{18} \mathrm{O}$ e ${ }^{2} \mathrm{H}$ nello studio delle idrostrutture carbonatiche abruzzesi e delle acque mineralizzate nell'area abruzzese e molisana. Giorn. Geol. Appl. 2005, 2, 453-458.

51. Gerali, F. Imprenditoria e scienza nell'industria petrolifera abruzzese del XIX secolo. Gli anni dell'energia. Energia 2013, 2, 50-55.

52. Gerali, F. Oil research in Italy in the second half of the nineteenth century: The birth of the modern oil industry in Abruzzo and the geological contributions of Giovanni Capellini. In History in Mineral Resources; Ortiz, J.E., Puche, O., Rabano, I., Mazadiego, L.F., Eds.; Cuadernos del Museo Geominero: Madrid, Espana, 2011; pp. 201-211.

53. Giattini, G.B. Osservazioni geologiche sopra i terreni Terziari di San Valentino (Chieti) e sopra i loro giacimenti di bitume. Giornale di Geologia Pratica 1907, 5-6, 169-197.

54. Lipparini, L.; Gerali, F.; Palladini, J. Early Oil Explorers in Italy across the '800 and '900: The North Maiella-Tocco Casauria Oil Province Case Histories (Abruzzo-Italy). In Proceedings of the International Conference \& Exhibition, Barcelona, Spain, 3-6 April 2016.

55. Principi, P. Osservazioni geologiche e morfologiche sulla valle della Pescara (Abruzzi). L'Universo 1930, 55, 3-24.

56. Massimi, G. L'Abruzzo-Tocco da Casauria e il Bel Paese; Itinerari: Enna, Italy, 2002.

57. Rusi, S.; Di Curzio, D.; Palmucci, W.; Petaccia, R. Detection of the natural origin hydrocarbon contamination in carbonate aquifers (central Apennine, Italy). Environ. Sci. Pollut. Res. 2018, 25, 15577-15596. [CrossRef] [PubMed]

58. Squarzina, F. Le Ricerche di Petrolio in Italia. Cenni Storici dal 1860 e Cronache Dell'ultimo Decennio. Available online: http:/ / www.pionierieni.it/wp/wp-content/uploads/EBOOK-10-Le-ricerche-di-petrolioin-Italia.-F.-Squarzina-1958.pdf (accessed on 10 July 2018).

59. Stoppani, A. Il Bel Paese. 41-Esima Edizione Economica; Cogliati Ed.: Milano, Italy, 1897.

60. Trapani, F. L'Oleum Petronicum, un antico rimedio galenico delle falde settentrionali della Majella. In Annuario del ClubAlpino Italiano; Sezione di Pescara: Pescara, Italy, 2003; pp. 61-76.

61. Verlengia, F. Bitumi e Petrolio nella Valle della Pescara attraverso i secoli. In Attraverso l'Abruzzo; Tip. Abruzzese: Pescara, Italy, 1956.

62. Bellatalla, M. Caratterizzazione Stratigrafica dei Depositi Miocenici e Pliocenici Della Maiella. Ph.D. Thesis, Università Degli Studi di Pisa, Pisa, Italy, 1992.

63. Carboni, M.G.; Civitelli, G.; Corda, L.; Esu, D.; Matteucci, R.; Palagi, I. Evoluzione delle facies e delle comunità bentoniche dal continentale al marino nel Miocene superiore della Valle del Fiume Aventino [Evolution of facies and benthic communities from continental to marine in the upper Miocene of the Aventino River Valley]. In Proceedings of the Libro-Guida Delle Escursioni. Quinto Simposio di Ecologia e Paleoecologia delle Comunità Bentoniche, Roma, Italy, 28-30 September 1992; pp. 110-120.

64. Patacca, E.; Scandone, P.; Bellatalla, M.; Perilli, N.; Santini, U. La zona di giunzione tra l'arco appenninico settentrionale e l'arco appenninico meridionale nell'Abruzzo e nel Molise. In Studi Preliminari All'acquisizione Dati del Profilo CROP 11 Civitavecchia-Vasto; Tozzi, M., Cavinato, G.P., Parotto, M., Eds.; Available online: https:/ / www.researchgate.net/publication/267506903_La_Zona_di_Giunzione_tra_L'arco_Appenninico_ Settentrionale_e_L'arco_Appenninico_Meridionale_Nell'abruzzo_e_nel_Molise (accessed on 10 July 2018).

65. Mazza, P.; Rustioni, M.; Aruta, G.; Di Carlo, E. A Messinian Prolagus from Capo di Fiume Quarry (Palena, Abruzzo, Central Italy). Boll. Soc. Pal. Ital. 1995, 34, 55-66.

66. Miccadei, E.; Parotto, M. Assetto geologico strutturale delle dorsali Rotella-Pizzalto-Porrara (Appennino abruzzese orientale). Geol. Rom. 1998, 34, 87-113.

67. Carnevale, G.; Patacca, E.; Scandone, P. Vertebrate Migration in the Mediterranean \& Paratethys-Neogene Park. Available online: https://www.researchgate.net/publication/256714795_Neogene_Park_-_ Vertebrate_Migration_in_the_Mediterranean_and_Paratethys (accessed on 10 July 2018). 
68. Teodoridis, V.; Kvače, Z.; Agostini, S.; Martinetto, E.; Rossi, M.A.; Cavallo, O. Feather palm foliage from the Messinian of Italy (Capo di Fiume, Palena and Pollenzo near Alba) within the framework of northern Mediterranean late Miocene flora. Acta Mus. Nat. Pragae Ser. B Hist. Nat. 2015, 72, 301-314.

69. Fiorillo, F.; Petitta, M.; Preziosi, E.; Rusi, S.; Esposito, L.; Tallini, M. Long-term trend and fluctuations of karst spring dischargein a Mediterranean area (central-southern Italy). Environ. Sci. Pollut. Res. 2015, 74, 153-172.

70. Nanni, T.; Rusi, S. Idrogeologia del massiccio carbonatico della montagna della Majella (Appennino centrale). Boll. Soc. Geol. Ital. 2003, 122, 173-202.

71. Forti, P.; Rossi, A. Le straordinarie concrezioni della Grotta Nera di Pennapiedimonte. In Parco Nazionale Della Majella. La Montagna dei Lupi, Degli Orsi e dei Santi Eremiti; Latini, M.L., Burri, E., Eds.; Carsa Edizioni: Pescara, Italy, 2003; p. 272.

72. Cacchio, P.; Ferrini, G.; Ercole, C.; Del Gallo, M.; Lepidi, A. Biogenicity and Characterization of Moonmilk in the Grotta Nera (Majella National Park, Abruzzi, Central Italy). J. Cave Karst Stud. 2014, 76, 88-103. [CrossRef]

(c) 2018 by the authors. Licensee MDPI, Basel, Switzerland. This article is an open access article distributed under the terms and conditions of the Creative Commons Attribution (CC BY) license (http://creativecommons.org/licenses/by/4.0/). 